\title{
Prediction sceptics 'must tackle bias' in earthquake research
}

London. Scientists who are sceptical that earthquakes can be predicted claim their views are being ignored and their research funding applications rejected because of bias by governments and the media.

Delegates at an international meeting of earthquake prediction sceptics in London last week said they were perplexed at the level of support for research into earthquake prediction, given that most predictions had failed. Many criticized what they considered unbalanced media coverage of earthquake prediction claims.

Russ Evans, head of regional geophysics at the British Geological Survey and one of the meeting's organizers, said studies that seek to reduce earthquake hazards are being underfunded because of prediction research. Fellow 'sceptics' should counter the public's tendency to believe in prediction claims, he said.

The two-day meeting was organized by the Royal Astronomical Society and the Association for Geophysics. Perhaps unsurprisingly, a consensus emerged that the influence of the earthquake prediction community is disproportionate to the scientific strength of its claims.

"If you give two proposals to a government, one of which says 'we predict an earthquake', the other that 'we want to do some basic research', guess which one gets the money," said Robert Geller, an associate professor at Tokyo University.

According to Geller, a century of earthquake prediction research has yielded little of significance beyond "specious claims of breakthroughs". Much of the blame, he said, lies with those who announce their claims without peer review.

Stathis Stiros, a researcher at the Institute of Geology and Mineral Exploration in Athens, said Greece's government is spending too much of the country's scarce research funding on earthquake prediction. "We should spend more on reinforcing our buildings."

But Bill Ellsworth, a geophysicist at the US Geological Survey in Menlo Park in California, says most earthquake research in the United States for the past decade has focused on the nature of earthquakes and on hazard reduction. "We don't do 'black box' predictions."

Ellsworth adds that researchers have made "enormous progress" over the past century. "We know where earthquakes occur. We understand more about the behaviour of complex fault systems over time and are making good progress towards long-term forecasts. This doesn't help you plan your weekend, but it helps reduce the risk to society." Ehsan Masood

\section{Roche claims victory in bid for European Taq patent}

London. For the second time in two years, the Swiss pharmaceutical company Hoffmann-la Roche says it has been told by the European Patent Office (EPO) that it is to be granted a broad European patent on thermostable enzymes used for the polymerase chain reaction (PCR) process.

According to company officials, the patent is "expected to be issued within the next six months". This follows a hearing at the EPO in Munich last week at which the company presented new evidence to counter claims that its discovery was not new, as the specific thermostable enzyme Taq DNA polymerase, obtained from the bacterium Thermus aquaticus, had previously been characterized by other researchers.

Two years ago, these claims were presented to the EPO examiners by rival companies, in particular the US laboratory equipment company Promega, which is currently being sued in the United States by Roche for infringing a licence to sell Taq polymerase. The patent office then suspended its previous decision to award the patent, saying that it wanted more information from Roche (see Nature 374, 108; 1995).

This summer, the examiners wrote to Roche saying that they would not be able to grant the patent unless they received satisfactory answers to key questions. They wanted more proof that the work carried out by David Gelfand and other scientists at Cetus, from which Roche bought the rights to Taq in 1991 as part of a US\$300-million package involving PCR technology, represented a significant step beyond those of previous researchers. Roche officials say that it was after they had produced such evidence at last week's meeting that the examiners agreed to issue the patent.

The EPO's decision gives Hoffmannla Roche broad rights to a range of

\section{India commissions its thorium reactor}

New Delhi. India's efforts to produce nuclear power from its supplies of thorium passed a significant milestone this month with the commissioning of a research reactor fuelled entirely by uranium-233 produced from thorium.

The Department of Atomic Energy (DAE) claims that the reactor, at the Indira Gandhi Centre for Atomic Research at Kalpakkam near Madras, is the only one in the world using such man-made material. It is also one of the smallest, using barely 600 grams of fuel to produce peak power of 30 kilowatts.

The reactor has been named Kamini, thermostable enzymes with a molecular weight of between 86,000 and 90,000 daltons. According to Tom White, vice-president of research and development at Roche Molecular Systems in New Jersey, these include the DNA polymerases from Thermococcus littoralis (known as 'VENT'), and Pyrococcus furiosis ('Pfu'). As a result, the company has been given the right to royalties from producers of both enzymes.

White said last week that Roche welcomed the approval of the patent as "an important recognition of the biochemical facts that clearly distinguishes the invention of our scientists from prior work". The patent covers both natural and recombinant forms of thermostable DNA polymerases, and Roche officials say they have already negotiated licences with 18 suppliers.

The European decision is likely to be studied closely by attorneys for both Roche and Promega. In the US dispute, Promega has issued a counter-challenge to Roche, challenging the validity of the US patent and alleging that misleading information was deliberately used in the original patent legislation (see Nature 382, 660; 1996) . A hearing of the case is due to be held in San Francisco on 13 December, having been delayed from last month at Roche's request.

Officials at Promega remain defiant. Randy Diamond, chief technical officer, said in a statement that "virtually the entire scientific community has acknowledged that any claim to native Taq DNA polymerase lacks novelty. Roche's latest statement does not dispute that basic premise". Roche, meanwhile, claims that Promega has "misrepresented the litigation and the science involved" and has "engaged in an aggressive public relations campaign to obscure the purely commercial nature of their interest in the PCR patents".

David Dickson short for 'Kalpakkam mini'. Rajagopala Chidambaram, secretary of the department, describes its successful commissioning as a "small but significant step towards the long-term goal of exploiting our thorium reserves".

India has 400,000 tonnes of thorium metal locked up in monazite-rich beach sands. Its energy content is equivalent to 500 billion tonnes of coal - sufficient to meet India's energy needs for several centuries. By itself thorium is not a nuclear fuel. But when exposed to neutrons it turns into fissile U-233, which can be separated by a chemical process.

K. S. Jayaraman 